\title{
Sistem Orientasi Objek Dengan Metode Stereo Vision Berbasis Raspberry Pi
}

\author{
Rajali Ginting ${ }^{1}$, Raditiana Patmasari ${ }^{2}$, Suci Aulia ${ }^{3}$ \\ Jurusan Teknik Telekomunikasi, Fakultas Teknik Elektro, Universitas Telkom ${ }^{1,2}$ \\ Fakultas Ilmu Terapan, Universitas Telkom ${ }^{3}$ \\ E-mail: rajali@student.telkomuniversity.ac.id ${ }^{1}$, raditiana@telkomuniversity.ac.id ${ }^{2}$, \\ sucia@tass.telkomuniversity.ac.id ${ }^{3}$
}

\begin{tabular}{l} 
Article Info \\
\hline History : \\
Dikirim \\
Direvisi \\
Diterima \\
\hline
\end{tabular}

\section{Kata Kunci :}

Canny edge detection

Disparitas citra

Harris corner detection

Hough line transform

Stereo vision

\begin{abstract}
Abstrak
Pengukuran estimasi jarak sebuah objek dapat dilakukan dengan berbagai cara, antara lain dengan memanfaatkan sensor pengukur jarak seperti sensor ultrasonik, sensor infra merah dan laser. Tetapi cara tersebut memiliki kekurangan seperti memiliki batasan-batasan karakteristik bahan yang digunakan dan memiliki kesulitan tersendiri jika dikaitkan dengan orientasi dimana objek tersebut berada.

Berdasarkan kekurangan tersebut maka pada penelitian ini akan dirancang suatu sistem pengukuran orientasi objek menggunakan metode stereo vision yang berbasis Raspberry pi. Sistem orientasi objek ini mengacu pada estimasi jarak dan dimensi objek. Metode stereo vision melakukan pengukuran jarak dan dimensi secara visual dengan menggunakan dua buah kamera webcam. Akusisi citra dilakukan dalam interval waktu yang bersamaan, sehingga akan terdapat dua citra yang memiliki objek yang sama tetapi dari sudut pandang yang berbeda. Kedua citra akan digunakan untuk menghitung nilai disparitas yang akan digunakan sebagai salah satu parameter dalam melakukan pengukuran jarak.

Menghitung nilai disparitas citra dilakukan menggunakan beberapa metode image processing yaitu menggunakan deteksi tepi Canny edge, deteksi garis Hough line transform dan deteksi sudut Harris corner. Penelitian ini dapat digunakan sebagai alat pengukuran jarak dan dimensi objek yang bergerak secara real time dengan tingkat akurasi diatas $95 \%$ dengan tingkat presisi $100 \%$.
\end{abstract}

(C) This work is licensed under a Creative Commons AttributionShareAlike 4.0 International License..

\author{
Koresponden: \\ Rajali Ginting, \\ Program Studi Teknik Telekomunikasi, Fakultas Teknik Elektro \\ Universitas Telkom, \\ Jl.Telekomunikasi No.1, Bandung, Indonesia, 40287 \\ Email : Rajaliginting@gmail.com
}

\section{PENDAHULUAN}

Pengukuran jarak dan dimensi suatu objek menjadi hal yang penting dalam berbagai aplikasi, terutama dalam sistem otonom bergerak [1]. Informasi tentang jarak dan ukuran objek yang berada disekeliling berguna untuk navigasi dan identifikasi sekitar. Terdapat dua metode yang sering digunakan untuk mengukur jarak, yaitu dengan menggunakan metode aktif dan metode pasif. Metode aktif bekerja dengan cara mengirimkan sinyal kepada objek yang akan diukur, seperti penggunaan sensor ultrasonik [2], sinar laser dan sensor infra merah [3], sedangkan metode pasif bekerja tanpa 
mengirimkan sinyal ke objek seperti penggunakan citra kamera. Stereo vision merupakan sistem yang memiliki konfigurasi menggunakan dua buah kamera yang memiliki karakteristik yang sama dan dipasang sejajar dengan jarak tertentu [4] [5].

Sebagian besar sistem otonom bergerak saat ini dilengkapi dengan sensor jarak menggunakan kamera. Beberapa karya penelitian sebelumnya menggunakan konfigurasi kamera stereo dengan tujuan pengukuran jarak objek. Sebagai contoh, Tsung-Shiang Hsu dan Ta-Chung Wang dengan judul penelitian "An Improvement Stereo Vision Images Processing for Object Distance Measurement" [6]. Penelitian tersebut menggunakan metode Speed up Robust feature (SURF) untuk melakukan pengukuran jarak objek dengan tingkat ketelitian diatas 95\%. Irfan Marzuqi dan Agus Khumaidi dengan judul penelitian "Segmentasi dan Estimasi Jarak Bola dengan Robot Menggunakan Stereo Vision" [7].menggunakan metode principal point dari bidang proyeksi dengan tingkat ketelitian diatas 95\%. Yasir M Mustafah, dkk dengan judul penelitian "Stereo Vision Images Processing for Real-Time Object Distance and Size Measurements" [8]. Menggunakan metode Morphology and Connected Component Analysis (CCA) dan blob tracking dengan tingkat ketelitian yang baik.

Berdasarkan kelebihan tersebut maka pada penelitian ini akan dirancang suatu sistem pengukuran orientasi objek menggunakan metode stereo vision yang berbasis Raspberry pi. Sistem orientasi objek ini mengacu pada estimasi jarak dan dimensi objek. Akusisi citra objek dilakukan dengan menggunakan dua kamera webcam dalam interval waktu yang bersamaan. Masalah yang akan ditemui pada saat menggunakan metode stereo vision adalah mencari nilai disparitas dari kedua citra [9]. Nilai disparitas sangat bergantung pada hasil pencarian piksel yang sama dari kedua citra yang diambil oleh kamera. Pada penelitian ini proses pencarian piksel tersebut dilakukan menggunakan beberapa metode image processing yaitu menggunakan deteksi tepi Canny edge, deteksi garis Hough line transform dan deteksi sudut Harris corner. Sehingga penelitian ini dapat digunakan sebagai alat pengukur estimasi jarak antara objek dengan kamera dan pengukuran dimensi objek yang bekerja secara real time.

\section{Dasar Teori}

\subsection{Citra}

Secara umum citra merupakan suatu foto, gambar atau berbagai visualiasi objek yang ditampilkan secara dua dimensi. Citra dapat direpresentasikan dalam bentuk digital maupun tercetak. Citra digital merupakan kumpulan angka - angka dalam dua dimensional. Angka - angka pada citra merupakan hasil kuantifikasi dari intensitas tingkat kecerahan dari masing - masing piksel penyusun citra. Piksel merupakan bagian elemen terkecil penyusun citra, jumlah piksel per unit panjang dalam citra dikenal sebagai resolusi citra. Semakin tinggi resolusi suatu citra maka jumlah piksel penyusunnya akan semakin banyak.

\subsection{Raspberry pi}

Raspberry pi merupakan sebuah Personal Computer (PC) yang memiliki ukuran yang kecil, tetapi berbeda dengan laptop maupun PC karena Raspberry pi dapat digunakan untuk proyek elektronika, namun Raspberry Pi juga dapat melakukan apa yang dapat dilakukan PC. Raspberry pi hanya memiliki RAM sebesar $512 \mathrm{MB}$ hingga $1 \mathrm{~GB}$ dan memiliki prosesor ARM dan pengolah grafik.

Raspberry pi juga memiliki sistem operasi seperti PC pada umunya, bernama Raspbian namun dapat juga di installasi sistem operasi lainnya seperti Ubuntu Mate, Windows, dan berbagai macam sistem operasi lainnya. Raspberry pi memiliki beberapa General Pin Input/Output (GPIO). GPIO dapat digunakan untuk berinteraksi dengan rangkaian elektronika, seperti untuk mengaktifkan sensor maupun menjalankan rangkaian lainnya. Setiap pin GPIO memiliki fungsinya masing-masing dimana terdapat pin yang dapat diprogram dan ada yang tidak dapat diprogram [11].

\subsection{Webcam}

Webcam merupakan suatu perangkat yang berupa kamera yang digunakan sebagai pengambil citra/gambar dan memiliki mikropon (optional) digunakan sebagai pengambil suara/audio yang dapat dikendalikan oleh sebuah komputer atau suatu jaringan komputer. Citra yang diambil oleh 
webcam akan ditampilkan ke layar monitor. Karena webcam dikendalikan oleh komputer maka terdapat interface atau port yang digunakan untuk menghubungkan webcam dengan komputer.

\subsection{Stereo vision}

Stereo vision merupakan suatu cara yang digunakan untuk mendapatkan citra stereo dari suatu objek menggunakan dua posisi kamera yang berbeda. Citra stereo didapatkan menggunakan dua kamera yang diletakkan pada bidang sejajar dengan jarak tertentu. Citra stereo yang digunakan untuk mencari nilai disparias, nilai tersebut dapat digunakan untuk menghitung jarak dan dimensi suatu objek dengan memprosesnya menggunakan beberapa metode image processing. Semakin besar nilai disparitas menunjukkan bahwa objek semakin dekat, begitupun dengan sebaliknya.

\subsection{Deteksi Tepi Canny edge}

Canny edge detection dikemukakan pada tahun 1986 oleh John Canny [12]. Canny edge merupakan salah satu teknik deteksi tepi yang cukup populer digunakan dalam pengolahan citra, dikarenakan metode deteksi tepi ini cukup optimal dengan tingkat kesalahan yang rendah. Canny edge melokalisasi posisi titik - titik edge pada citra setebal satu piksel sehingga didapat edge yang sepresisi mungkin.

\subsection{Hough Line Transform}

Hough line transform merupakan transformasi citra yang digunakan untuk memperoleh fitur dari sebuah gambar. Hough line Transform adalah salah satu teknik yang umum digunakan dalam sistem pengolahan citra untuk mendeteksi objek yang memiliki bentuk seperti garis. Keuntungan utama dari penggunaan metode transformasi Hough adalah dapat mendeteksi sebuah tepian atau edge secara relatif tidak terpengaruh oleh derau. Transformasi Hough bekerja menggunakan voting suara terbanyak untuk menentukan nilai parameter yang paling tepat. Apabila didalam sebuah citra yang telah ditransformasikan ke dalam ruang parameter $\mathrm{m}-\mathrm{c}$ terdapat beberapa garis yang saling berpotongan pada sebuah titik. Untuk mengetahui titik tersebut adalah sebuah garis lurus atau bukan didalam ruang parameter $\mathrm{x}-\mathrm{y}$ dilakukan voting menggunakan persamaan 3 .

$$
y=m x+c
$$

Apabila di dalam citra terdapat sebuah garis lurus yang memiliki persamaan yang sama dengan persamaan (1.3), kemudian garis tersebut ditransformasikan ke bentuk ruang parameter $\mathrm{m}-\mathrm{c}$ maka akan diperoleh beberapa garis yang saling berpotongan pada suatu titik. Transformasi tersebut diperoleh dengan cara melakukan perhitungan dari setiap titik pada citra kedalam nilai $\mathrm{m}-\mathrm{c}$ menggunakan persamaan 4 .

$$
\mathrm{c}=-\mathrm{mx}+\mathrm{y}
$$

Pada kenyataannya, apabila terdapat garis yang vertikal akan menjadi masalah didalam melakukan perhitungan, dikarenakan garis vertikal memiliki nilai gradien kemiringan $\mathrm{m}$ yang nilainya tak terhingga. Untuk mengatasi masalah tersebut dapat menggunakan persamaan 5.

$$
\rho=x \cos \theta+y \sin \theta
$$

Dari persamaan 5 dilakukan trasformasi garis lurus kedalam ruang parameter $\rho$ (rho) - $\Theta$ (theta) yang akan mengkibatkan penumpukan antar kurva sinusoida di suatu titik [13].

\subsection{Harris Corner Detection}

Sudut merupakan suatu titik yang memiliki lingkungan lokal terdiri dari dua arah tepi atau edge yang dominan dan berbeda. Sudut juga dapat diartikan sebagai persimpangan yang memiliki dua sisi, dimana sisi memiliki intensitas kecerahan yang tiba-tiba berubah dalam suatu citra. Harris corner detection merupakan operator yang dapat digunakan untuk mendeteksi suatu sudut karena dapat membedakan antara tepi dengan sudut secara akurat, karena akan menghasilkan nilai yang konsiten dari suatu citra walaupun telah mengalami rotasi, penskalaan, variasi pencahayaan ataupun memiliki derau didalamnya [14]. Harris corner akan mendeteksi sudut dengan cara memperhitungkan variasi nilai intensitas dari suatu citra menggunakan suatu jendela biner yang digeser ke arah sumbu x dan sumbu y. Untuk mencari variasi nilai intensitasnya dapat menggunakan persamaan 6. 


$$
\begin{aligned}
E(\mathrm{u}, \mathrm{v}) & =\sum_{\mathrm{x}, \mathrm{y}} \mathrm{w}(\mathrm{x}, \mathrm{y})[\mathrm{I}(\mathrm{x}+\mathrm{u}, \mathrm{y}+\mathrm{v})-\mathrm{I}(\mathrm{x}, \mathrm{y})]^{2} \\
& =\sum \mathrm{u}^{2} \mathrm{I}_{\mathrm{x}}^{2}+2 \mathrm{uvI}_{\mathrm{x}} \mathrm{I}_{\mathrm{y}}+\mathrm{v}^{2} \mathrm{I}_{\mathrm{y}}^{2} \\
& =\sum[\mathrm{u} \mathrm{v}]\left[\begin{array}{cc}
\mathrm{I}_{\mathrm{x}}^{2} & \mathrm{I}_{\mathrm{x}} \mathrm{I}_{\mathrm{y}} \\
\mathrm{I}_{\mathrm{x}} \mathrm{I}_{\mathrm{y}} & \mathrm{I}_{\mathrm{y}}^{2}
\end{array}\right]\left[\begin{array}{l}
\mathrm{u} \\
\mathrm{v}
\end{array}\right] \\
& =[\mathrm{u} \mathrm{v}]\left(\sum\left[\begin{array}{cc}
\mathrm{I}_{\mathrm{x}}^{2} & \mathrm{I}_{\mathrm{x}} \mathrm{I}_{\mathrm{y}} \\
\mathrm{I}_{\mathrm{x}} \mathrm{I}_{\mathrm{y}} & \mathrm{I}_{\mathrm{y}}^{2}
\end{array}\right]\right)\left[\begin{array}{l}
\mathrm{u} \\
\mathrm{v}
\end{array}\right]
\end{aligned}
$$

dimana :

$\mathrm{E}=$ perbedaan antara jendela asli dengan jendela yang digeser.

$\mathrm{u}=$ pergeseran jendela ke arah sumbu $\mathrm{x}$.

$\mathrm{v}=$ pergeseran jendela ke arah sumbu $\mathrm{y}$.

$\mathrm{w}(\mathrm{x}, \mathrm{y})=$ fungsi jendela pada posisi $\mathrm{x}$ dan $\mathrm{y}$.

$\mathrm{I}(\mathrm{x}+\mathrm{u}, \mathrm{y}+\mathrm{v})=$ intensitas pergeseran jendela

$\mathrm{I}(\mathrm{x}, \mathrm{y})=$ intensitas asli.

\subsection{Parameter Pengukuran Jarak dan Dimensi}

Langkah awal dalam menghitung jarak dan dimensi objek adalah melakukan konversi piksel kedalam sentimeter. Konversi piksel dilakukan menggunakan persamaan 7.

$$
\text { Ukuran piksel }=\frac{(\text { Focal Length }) \times(\text { Ukuran Objek sebenarnya })}{(\text { Jarak kamera dengan objek }) \times(\text { Jumlah Piksel Objek Sumbu } x)}
$$

Setelah ukuran piksel didapatkan, selanjutnya melakukan pengukuran jarak antara objek dengan kamera menggunakan persamaan 8 .

$$
\text { Jarak }=\frac{(\text { Focal Length }) \times(\text { Baseline Kamera })}{(\text { Disparitas }) \times(\text { Ukuran Piksel })}
$$

Untuk dapat melakukan pengukuran dimensi panjang dan tinggi objek dengan jarak yang berubah ubah digunakan persamaan 9 dan 10 .

$$
\begin{gathered}
\text { Panjang Objek }=\frac{(\text { Jarak }) \times(\text { Ukuran Piksel }) \times(\text { Jumlah Piksel Objek Sumbu x })}{(\text { Focal Length })} \\
\text { Tinggi Objek }=\frac{(\text { Jarak }) \times(\text { Ukuran Piksel }) \times(\text { Jumlah Piksel Objek Sumbu y })}{(\text { Focal Length })}
\end{gathered}
$$

Dimana :

Focal length $=4.4 \mathrm{~mm}$ (berdasarkan spesifikasi kamera).

Baseline $=260 \mathrm{~mm}$ (jarak antar kamera)

\section{Model Sistem}

\subsection{Perancangan Sistem}

Adapun blok diagram sistem yang akan dirancang adalah seperti gambar 1 .

Akusisi Citra $\rightarrow \begin{gathered}\text { Proses sistem } \\ \text { stereo vision }\end{gathered} \rightarrow \begin{gathered}\text { Jarak dan ukuran } \\ \text { objek terukur }\end{gathered}$

\subsection{Akusisi Citra}

Gambar 1. Blok diagram perancangan sistem

Proses akusisi citra ini dilakukan dengan menggunakan dua buah kamera webcam yang dipasang sejajar dengan jarak baseline $26 \mathrm{~cm}$. Pengambilan citra dilakukan dalam selang waktu yang bersamaan. Sehingga akan menghasilkan dua buah citra dengan objek yang sama, tetapi dengan sudut pandang berbeda. Gambar 2 merupakan hasil akusisi citra menggunakan kamera stereo dengan jarak kamera dengan objek sejauh 1 meter. 


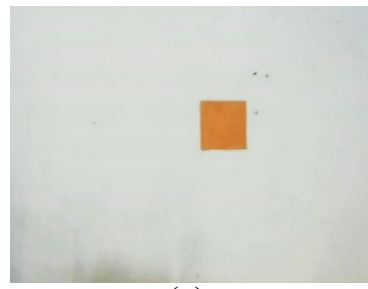

(a)

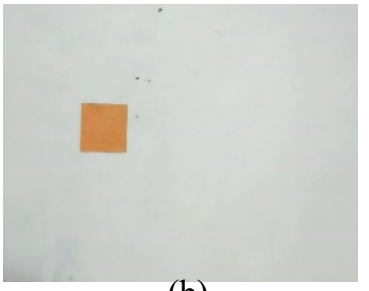

(b)

Gambar 2. (a) Citra kanan. (b) Citra kiri

\subsection{Proses Sistem Stereo vision}

Adapun tahap dan metode yang dilakukan untuk memproses citra dapat dilihat pada diagram alir gambar 3 .

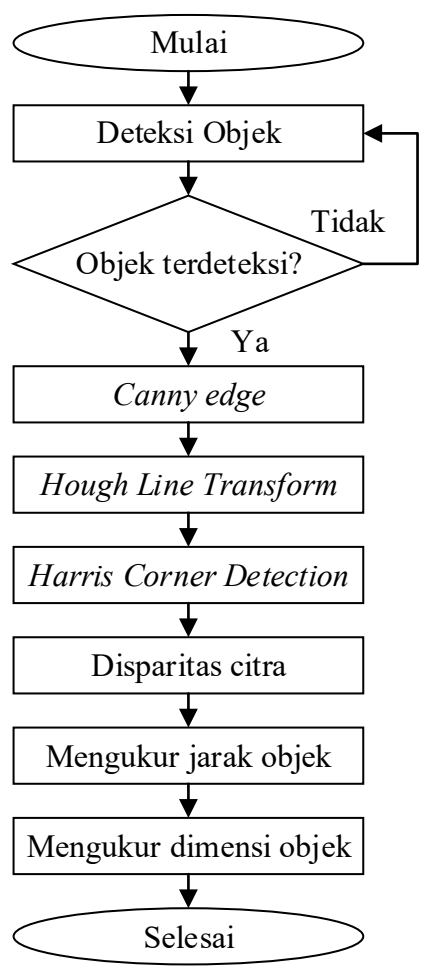

Gambar 3. Diagram alir proses stereo vision

Tahap - tahap tersebut meliputi akusisi citra, deteksi objek, deteksi tepi menggunakan operator Canny edge, deteksi garis menggunakan metode Hough line transform, deteksi sudut menggunakan metode Harris corner dan menghitung perbedaan nilai disparitas antar kedua citra. Penjabaran berikut ini hanya menjelaskan proses satu buah citra, dikarenakan proses kedua citra yang sama.

\subsection{Mendeteksi Objek}

Deteksi objek dilakukan dengan segmentasi warna. Segmentasi warna bertujuan untuk memisahan antara warna objek dengan warna latar belakangan pada citra. Format citra RGB yang dihasilkan pada saat melakukan akusisi citra kemudian dikonversi kedalam format $\mathrm{YCbCr}$. Untuk mendeteksi warna dilakukan menggunakan dua nilai threshold yaitu minimun dan maksimum intensitas nilai piksel pada objek. Untuk nilai yang memiliki intensitas diluar nilai threshold akan diubah menjadi piksel 0 atau warna hitam, karena akan diaggap sebagai warna latar belakang seperti pada gambar 4. 


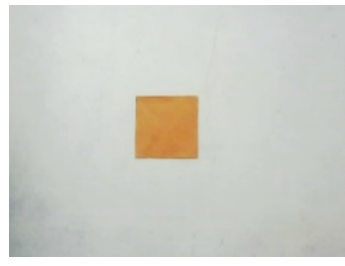

(a)

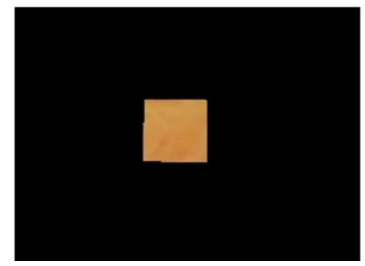

(b

Gambar 4. (a) Citra asli. (b) Hasil Deteksi warna

\subsubsection{Deteksi Tepi Canny Edge}

Secara ringkas metode Canny edge akan dijelaskan sebagai berikut :

1. Proses pertama dalam melakukan deteksi tepi adalah mengubah citra kedalam bentuk grayscale.

2. Selanjutnya citra dihaluskan menggunakan filter Gaussian.

3. Hitung nilai gradien horizontal dan vertikal pada citra dengan melakukan konvolusi menggunakan operator Sobel.

4. Hitung magnitude dan arah magnitude citra.

5. Setelah arah tepi didapatkan, selanjutnya melakukan proses Non-maximum suppression untuk menekan atau menghilangkan piksel - piksel yang tidak memiliki nilai maksimum, disepanjang garis tepi dan searah dengan garis tepi. Sehingga menghasilkan garis tepi yang presisi setebal satu piksel.

6. Pada proses Non-maximum Suppression yang belum maksimal mengakibatkan beberapa tepi yang sebenarnya bukan tepi akan terdeteksi yang diakibatkan oleh noise pada citra. Double Thresholding digunakan untuk menangani masalah tersebut dikarenakan memiliki dua thresholding yaitu low thresholding dan high thresholding. Low thresholding berfungsi untuk mengubah semua nilai piksel dibawah thresholding tersebut bernilai 0 sedangkan High thresholding berfungsi untuk membuat semua nilai piksel diatas nilai tersebut menjadi bernilai 1. Sehingga dengan menggunakan Double Thresholding deteksi tepi dapat dilakukan dengan lebih maksimal.

7. Langkah terakhir melakukan proses untuk memutuskan semua tepi yang terdeteksi benar - benar tepi dan mana yang bukan tepi. Oleh karena itu, proses ini mengacu pada nilai double thresholding. Untuk setiap tepi dengan intensitas nilai lebih tinggi dari nilai high threshoding dipastikan sebagai tepi sebenarnya, sedangkan intensitas dibawah nilai low thresholding dipastikan bukan tepi sehingga akan dihilangkan. Sedangkan untuk intensitas nilai tepi yang berada diantara kedua nilai thresholding akan diklasifikasikan menjadi tepi atau bukan tepi berdasarkan konektivitas tepi tersebut. Apabila tepi tersebut terhubung dengan piksel yang tepi sebenarnya, maka tepi tersebut akan dianggap sebagai bagian dari tepi sebenarnya, apabila tidak terhubung dengan tepi sebenarnya maka akan dihilangkan. Gambar 5 dibawah merupakan hasil deteksi menggunakan metode Canny edge.

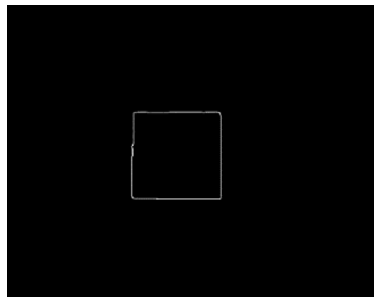

Gambar 5. Hasil deteksi Canny edge

\subsubsection{Hough Line Transform}

Metode Hough line transform digunakan untuk memperbaiki garis tepi yang tidak sempurna dari hasil keluaran deteksi tepi Canny edge. Perbaikan garis tepi dilakukan dengan cara mengganti garis tepi dengan garis tepi yang baru dari hasil deteksi Hough line transform. Sehingga akan dihasilkan objek dengan sudut yang sempurna, untuk memaksimalkan perhitungan untuk mencari nilai disparitas menggunakan deteksi sudut Harris corner. Hasil deteksi garis dari keluaran Canny edge menggunakan hough line transform seperti pada gambar 6. 


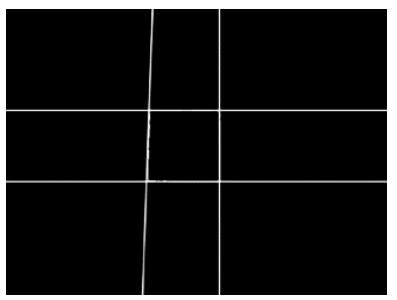

Gambar 6. Hasil deteksi Hough line transform

Dari hasil garis yang telah terdeteksi, selanjutnya dilakukan perbaikan tepi keluaran Canny edge menggunakan garis yang baru. Sehingga didapatkan sudut yang maksimal pada objek.

\subsubsection{Harris Corner Detection}

Metode Harris corner digunakan untuk mendeteksi sudut pada citra, yang bertujuan untuk mencari nilai disparitas antar kedua citra. Nilai disparitas digunakan sebagai salah satu parameter untuk menghitung jarak dan dimensi objek. Langkah pertama dalam mendeteksi sudut adalah mengubah citra hasil keluaran Hough line transform kedalam bentuk grayscale yang memiliki rentang nilai piksel 0 sampai 255 . Selanjutnya menghitung nilai gradien vertikal dan horizontal citra dengan melakukan konvolusi menggunakan kernel prewitt.

$$
\text { Prewitt } G_{x}=\left[\begin{array}{lll}
1 & 0 & -1 \\
1 & 0 & -1 \\
1 & 0 & -1
\end{array}\right] \quad \text { Prewitt } G_{y}=\left[\begin{array}{rrr}
1 & 1 & 1 \\
0 & 0 & 0 \\
-1 & -1 & -1
\end{array}\right]
$$

Setelah mendapatkan nilai gradien, kemudian hitung nilai turunan setiap piksel menggunakan persamaan 11.

$$
I_{x}{ }^{2}=I_{x} * I_{x} \quad I_{y}{ }^{2}=I_{y} * I_{y} \quad I_{x y}=I_{x} * I_{y}
$$

Konvolusi dengan filter Gaussian $\left(G_{\sigma}\right)$ untuk mencari jumlah nilai turunan produk tiap pikselnya dengan persamaan berikut ini.

$$
S_{x}{ }^{2}=I_{x}{ }^{2} \otimes G_{\sigma} \quad S_{y}{ }^{2}=I_{y}{ }^{2} \otimes G_{\sigma} \quad S_{x y}=I_{x y} \otimes G_{\sigma}
$$

Hasil konvolusi tersebut digunakan untuk membentuk matriks baru untuk menghitung nilai respon Harris. Nilai respon Harris didapatkan dengan menggunakan persamaan berikut.

$$
\begin{gathered}
\text { Matriks } H=\left[\begin{array}{ll}
S_{x}{ }^{2} & S_{x y} \\
S_{x y} & S_{y}{ }^{2}
\end{array}\right] \\
\text { Respon Harris }=\left(\left(S_{x}{ }^{2}\right) \cdot\left(S_{y}{ }^{2}\right)-\left(S_{x y}\right)^{2}\right)-k\left(\left(S_{x}{ }^{2}\right)+\left(S_{y}{ }^{2}\right)\right)^{2}
\end{gathered}
$$

Nilai respon Harris digunakan untuk menentukan piksel tersebut suatu sudut atau bukan. Apabila nilai respon lebih besar dari nilai threshold maka piksel tersebut akan dianggap sebagai suatu sudut. Gambar 7 merupakan hasil deteksi sudut menggunakan metode Harris corner.

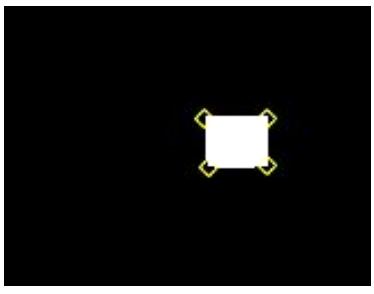

(a)

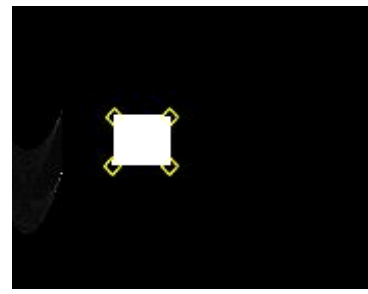

(b)

Gambar 7. (a) Deteksi sudut citra kanan. (b) Deteksi sudut citra kiri. 


\subsubsection{Menghitung Disparitas Citra}

Untuk menentukan nilai disparitas antar kedua citra, digunakan pengurangan posisi kolom pada titik piksel sudut yang dideteksi, kolom piksel pada sudut citra kanan dikurang dengan kolom pada sudut citra kiri, sehingga didapatkan hasil perbedaan jarak piksel diantara kedua citra. Posisi piksel dari hasil deteksi sudut menggunakan metode Harris corner ditunjukan pada gambar 8 .

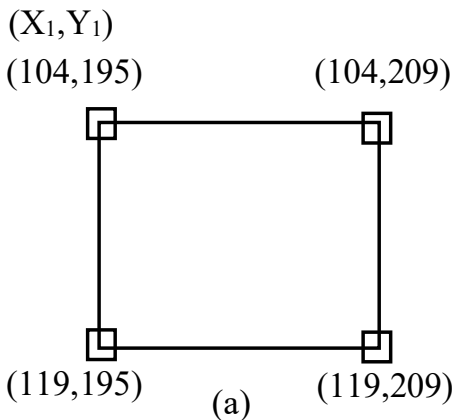

Gambar 8. (a) Posisi sudut citra kanan. (b) Posisi sudut citra kiri

Pada gambar 8 diatas (a) merepresentasikan citra yang diambil menggunakan webcam kanan dan (b) merepresentasikan citra yang diambil menggunakan webcam kiri. Hasil deteksi sudut digunakan untuk mencari nilai disparitas (D) citra dari kedua citra, dengan cara menghitung selisih posisi piksel antara kedua citra tersebut.

$$
|\mathrm{D}|=\left(\mathrm{Y}_{1}-\mathrm{Y}_{2}\right)=(195-144)=51
$$

Dari perhitungan diatas didapatkan nilai disparitas antara kedua citra adalah 51.

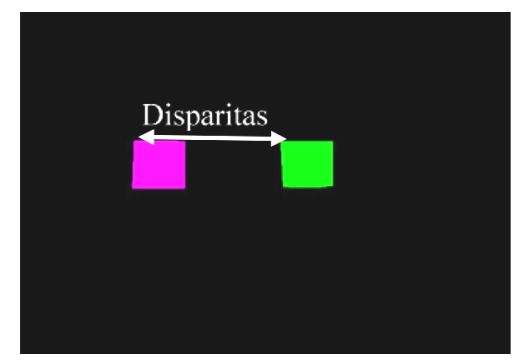

Gambar 9. Disparitas Citra

\subsection{Pengukuran Jarak dan Dimensi}

Dalam melakukan pengukuran jarak dan dimensi objek, langkah pertama adalah mengkonversi ukuran piksel ke dalam sentimeter menggunakan persamaan 7. Pada contoh kasus berikut, objek yang diukur memiliki dimensi panjang dan lebar $15 \times 10 \mathrm{~cm}$ dengan jarak pengambilan citra sejauh 1 meter.

$$
\text { Konversi ukuran piksel ke } \mathrm{cm}=\frac{(4.4 \mathrm{~mm}) \times(100 \mathrm{~mm})}{(1900 \mathrm{~mm}) \times(14)}=0.16532 \mathrm{~mm}
$$

Setelah melakukan konversi ukuran piksel, didapatkan ukuran piksel pada citra sebesar $0.16352 \mathrm{~mm}$. Selanjutnya melakukan pengukuran jarak antara objek dengan kamera menggunakan persamaan 8 .

$$
\text { Jarak }=\frac{(4.4 \mathrm{~mm}) \times(260 \mathrm{~mm})}{(51) \times(0.118 \mathrm{~mm})}=190 \mathrm{~cm}
$$

Pengukuran dimensi panjang dan lebar objek menggunakan persamaan 9 dan 10.

$$
\text { Panjang Objek }=\frac{(1900 \mathrm{~mm}) \times(0.16532 \mathrm{~mm}) \times(14)}{(4.4 \mathrm{~mm})}=10 \mathrm{~cm}
$$




$$
\text { Tinggi Objek }=\frac{(1900 \mathrm{~mm}) \times(0.16532 \mathrm{~mm}) \times(14)}{(4.4 \mathrm{~mm})}=10 \mathrm{~cm}
$$

\section{Pengujian dan Analisis}

Pengujian sistem dilakukan menggunakan dua kamera webcam yang terhubung dengan Raspberry pi 3. Program dijalankan menggunakan laptop dan dikirim ke Raspberry pi menggunakan sambungan wireless. Laptop yang digunakan memiliki spesifikasi dual-core $1.8 \mathrm{Ghz}$. Skema pengujian seperti pada gambar 10 .

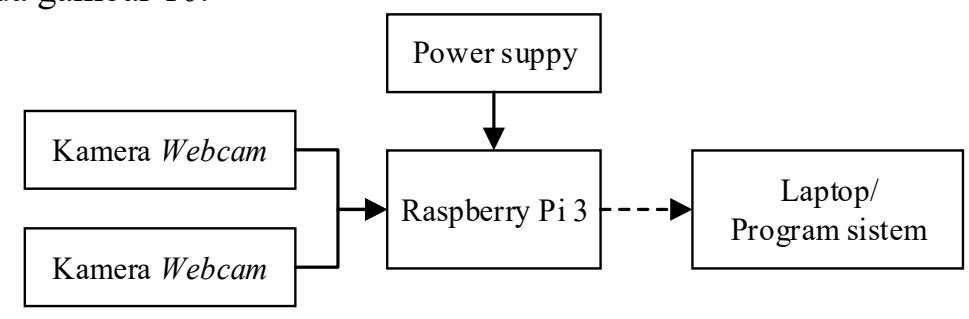

Gambar 10. Diagram perancangan perangkat keras

\subsection{Skema Pengujian}

Skema pengujian menggunakan objek yang memiliki bentuk sederhana seperti persegi, persegi panjang dan lingkaran. Objek yang akan diukur berada didepan kamera. Skema pengukuran objek seperti gambar 11 .

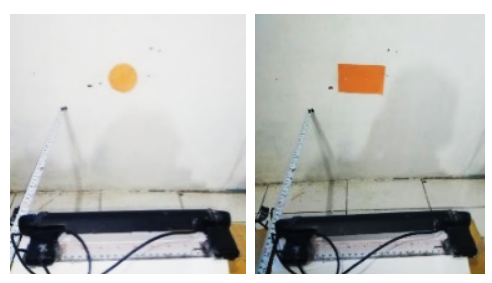

Gambar 11. Skema pengujian

Nilai yang akan diambil untuk menjadi data hasil pengukuran menggunakan skema pengulangan sebanyak 5 kali, dengan nilai yang paling banyak muncul yang akan dijadikan sampel nilai hasil. Nilai pengujian yang diambil seperti jarak, dimensi, nilai disparitas dan lama waktu komputasi. Hasil pengukuran jarak dibulatkan menggunakan ceil dan floor

\subsection{Pengujian Akurasi pengukuran}

Akurasi merupakan suatu sistem pengukuran dengan tingkat kedekatan hasil pengukuran terhadap nilai yang sebenarnya. Pengujian akurasi dilakukan untuk mengetahui tinggat keakuratan sistem dalam melakukan pengukuran.

\subsubsection{Pengujian Menggunakan Metode Canny Edge, Hough Line Transform dan Harris Corner.}

Pengujian ini bertujuan untuk mengetahui tingkat keakuratan sistem dan lama waktu komputasi apabila menggunakan ketiga metode Canny edge, Hough line transform dan Harris corner dalam stereo vision. Waktu komputasi merupakan hasil dari akumulasi setelah melakukan perulangan. Objek yang diukur memiliki bentuk segi empat dengan dimensi panjang dan lebar 10x10cm yang berada didepan kamera.

Tabel 1. Pengujian akurasi pengukuran segi empat

\begin{tabular}{|c|c|c|c|c|c|c|}
\hline \multicolumn{2}{|c|}{ Jarak (cm) } & \multirow{2}{*}{$\begin{array}{c}\text { Keakuratan } \\
\text { Jarak }(\%)\end{array}$} & \multirow{2}{*}{$\begin{array}{c}\text { Waktu } \\
\text { Komputasi } \\
\text { (detik) }\end{array}$} & \multicolumn{2}{|c|}{$\begin{array}{l}\text { Pengukuran } \\
(\mathrm{cm})\end{array}$} & \multirow{2}{*}{ Disparitas } \\
\hline Sebenarnya & Terukur & & & A & B & \\
\hline 50 & 48 & 96 & 23.6 & 10.2 & 10 & 206 \\
\hline 60 & 58 & 96.67 & 23.5 & 10.2 & 10 & 168 \\
\hline 70 & 69 & 98.57 & 23.2 & 10.1 & 10 & 143 \\
\hline 80 & 79 & 98.75 & 23.6 & 10 & 10 & 124 \\
\hline 90 & 89 & 98.89 & 23.7 & 9.9 & 10.1 & 110 \\
\hline
\end{tabular}


10IT Jou Res and Dev,, Vol.3, No.1, Maret 2018: 1 - 10

\begin{tabular}{|c|c|c|c|c|c|c|}
\hline 100 & 100 & 100 & 23.1 & 10 & 10 & 98 \\
\hline 110 & 111 & 99.09 & 23.5 & 9.9 & 9.9 & 88 \\
\hline 120 & 122 & 98.33 & 23 & 10.2 & 9.9 & 80 \\
\hline 130 & 135 & 96.15 & 23.5 & 9.9 & 9.9 & 72 \\
\hline 140 & 147 & 95 & 23.9 & 10 & 10 & 66 \\
\hline 150 & 158 & 94.67 & 22 & 9.8 & 9.8 & 62 \\
\hline Rata - rata & 97.4 & 23.3 & 10 & 9.9 & & \\
\hline
\end{tabular}

Hasil pengujian menggunakan ketiga metode yaitu Canny edge, Hough line transform dan Harris corner didapatkan pengukuran yang stabil. Dikarenakan setiap melakukan perulangan hasil pengukuran tidak berubah, tetapi memiliki kekurangan waktu komputasi yang besar dikarenakan penggunaan metode Hough line transform. Tabel 1 merupakan hasil pengukuran akurasi objek segiempat, dari pengujian yang dilakukan sebanyak 11 kali didapatkan tingkat keakuratan jarak sebesar $97.4 \%$ dengan rata - rata waktu komputasi 23.3 detik.

\subsubsection{Pengujian Menggunakan Metode Canny Edge dan Harris Corner.}

Pengujian ini bertujuan untuk mengetahui tingkat keakuratan sistem dan lama waktu komputasi apabila menggunakan dua metode yaitu Canny edge dan Harris Corner. Waktu komputasi merupakan hasil akumulasi selama melakukan perulangan. Objek yang diukur dengan bentuk segi empat memiliki dimensi panjang dan lebar $10 \times 10 \mathrm{~cm}$ yang berada didepan kamera.

Tabel 2. Pengujian akurasi pengukuran segi empat

\begin{tabular}{|c|c|c|c|c|c|c|}
\hline \multicolumn{2}{|c|}{ Jarak $(\mathrm{cm})$} & \multirow{2}{*}{$\begin{array}{c}\text { Keakuratan } \\
\text { Jarak }(\%)\end{array}$} & \multirow{2}{*}{$\begin{array}{c}\text { Waktu } \\
\text { Komputasi } \\
\text { (detik) }\end{array}$} & \multicolumn{2}{|c|}{$\begin{array}{l}\text { Pengukuran } \\
(\mathrm{cm})\end{array}$} & \multirow{2}{*}{ Disparitas } \\
\hline Sebenarnya & Terukur & & & $\mathrm{A}$ & B & \\
\hline 50 & 48 & 96 & 13.8 & 9.8 & 9.7 & 209 \\
\hline 60 & 59 & 98.33 & 13.2 & 10 & 9.8 & 171 \\
\hline 70 & 69 & 98.57 & 13.5 & 9.8 & 9.8 & 146 \\
\hline 80 & 79 & 98.75 & 13 & 9.8 & 9.8 & 129 \\
\hline 90 & 89 & 98.89 & 12.8 & 10 & 10 & 111 \\
\hline 100 & 100 & 100 & 13.4 & 10 & 10 & 102 \\
\hline 110 & 111 & 99.09 & 14.1 & 10.2 & 10.1 & 91 \\
\hline 120 & 123 & 97.5 & 12.8 & 10 & 10.3 & 82 \\
\hline 130 & 135 & 96.15 & 14 & 10.1 & 10.1 & 76 \\
\hline 140 & 144 & 97.14 & 14.7 & 10.3 & 10.3 & 70 \\
\hline 150 & 158 & 94.67 & 14.2 & 10.4 & 10.4 & 64 \\
\hline \multicolumn{2}{|c|}{ Rata - rata } & 97.7 & 13.5 & 10 & 10 & \\
\hline
\end{tabular}

$\mathrm{A}=$ Panjang Objek $\quad \mathrm{B}=$ Lebar Objek

Tabel 2 merupakan hasil pengukuran akurasi objek segi empat. Hasil pengujian dengan menggunakan dua metode yaitu Canny edge dan Harris corner didapatkan pengukuran yang kurang stabil. Dikarenakan setiap melakukan perulangan hasil pengukuran mengalami perubahan, tetapi memiliki kelebihan waktu komputasi yang kecil. Perubahan tersebut dikarenakan dari hasil keluaran Canny edge yang tidak sempurna, mengakibatkan sudut yang dideteksi oleh Harris corner berubah ubah. Dari pengujian yang dilakukan sebanyak 11 kali didapatkan tingkat keakuratan jarak sebesar $97.7 \%$ dengan rata - rata waktu komputasi 13.5 detik.

\subsubsection{Pengujian Menggunakan Metode Canny Edge}

Pengujian ini bertujuan untuk mengetahui tingkat keakuratan sistem dan lama waktu komputasi apabila hanya menggunakan metode canny edge dalam stereo vision. waktu komputasi merupakan hasil dari akumulasi selama melakukan perulangan sebanyak lima kali. Objek yang diukur memiliki bentuk segi empat dengan dimensi panjang dan lebar 10x10 $\mathrm{cm}$ yang berada didepan kamera. 
Tabel 3. Pengujian akurasi pengukuran segi empat

\begin{tabular}{ccccccc}
\hline \multirow{2}{*}{ Jarak $(\mathrm{cm})$} & \multirow{2}{*}{$\begin{array}{c}\text { Keakuratan } \\
\text { Sebenarnya }\end{array}$} & Terukur & Waktu & \multicolumn{2}{c}{$\begin{array}{c}\text { Pengukuran } \\
(\mathrm{cm})\end{array}$} & \multirow{2}{*}{ Disparitas } \\
\cline { 1 - 1 } \cline { 5 - 6 } Sarak $(\%)$ & Komputasi & & $\mathrm{A}$ & $\mathrm{B}$ & \\
\hline 50 & 48 & 96 & 9.7 & 9.7 & 9.9 & 212 \\
\hline 60 & 58 & 96.67 & 9.1 & 9.7 & 10 & 176 \\
\hline 70 & 68 & 97.14 & 9.9 & 9.7 & 10.1 & 150 \\
\hline 80 & 77 & 96.25 & 9.2 & 9.9 & 9.9 & 132 \\
\hline 90 & 88 & 97.78 & 8.9 & 10 & 10 & 116 \\
\hline 100 & 100 & 100 & 9.5 & 10 & 10.4 & 102 \\
\hline 110 & 109 & 99.09 & 9.6 & 10.3 & 10.3 & 94 \\
\hline 120 & 119 & 99.17 & 9.1 & 10.1 & 10.1 & 86 \\
\hline 130 & 131 & 99.23 & 8.5 & 10.5 & 10.5 & 78 \\
\hline 140 & 138 & 98.57 & 9.4 & 10.4 & 10.4 & 74 \\
\hline 150 & 150 & 100 & 9.2 & 10.6 & 10.6 & 68 \\
\hline Rata - rata & 98.17 & 9.28 & 10.08 & 10.2 & \\
\hline
\end{tabular}

$\mathrm{A}=$ Panjang Objek $\quad \mathrm{B}=$ Lebar Objek

Hasil pengujian hanya menggunakan satu metode Canny edge didapatkan hasil memiliki kelebihan waktu komputasi yang kecil. Dikarenakan hanya menggunakan satu metode sehingga meringankan beban komputasi. Pada tabel 3 hasil pengukuran akurasi objek segi empat. Dari pengujian yang dilakukan sebanyak 11 kali didapatkan tingkat keakuratan jarak sebesar $98.17 \%$ dengan rata - rata waktu komputasi 9.28 detik.

\subsection{Pengujian Presisi Pengukuran}

Presisi merupakan kedekatan perbedaan nilai saat melakukan pengulangan pengukuran [12]. Pengujian tingkat presisi dalam pengukuran dimensi objek dengan bentuk segi empat, persegi panjang dan lingkaran. Pengulangan pengukuran dilakukan sebanyak 5 kali. Setiap pengujian menggunakan metode yang berbeda - beda.

Tabel 4 merupakan pengujian presisi menggunakan tiga metode yaitu Canny edge, Hough line transform dan Harris corner. Objek yang diukur memiliki bentuk persegi panjang dengan dimensi $15 \times 10 \mathrm{~cm}$.

Tabel 4. Pengujian presisi objek persegi panjang

\begin{tabular}{ccccc}
\hline Jenis Objek & $\begin{array}{c}\text { Jarak } \\
\text { Pengukuran } \\
(\mathrm{cm})\end{array}$ & $\begin{array}{c}\text { Dimensi } \\
\text { Objek } \\
(\mathrm{cm})\end{array}$ & $\begin{array}{c}\text { Panjang } \\
\text { Objek } \\
\text { Terukur }(\mathrm{cm})\end{array}$ & $\begin{array}{c}\text { Lebar } \\
\text { Objek } \\
\text { Terukur }(\mathrm{cm})\end{array}$ \\
\hline & & & 15.02 & 9.58 \\
\hline Persegi Panjang & 100 & $15 \times 10$ & 15.02 & 9.58 \\
\hline & & & 15.02 & 9.58 \\
\hline & & & 15.02 & 9.58 \\
\hline & Presisi & & $100 \%$ & $100 \%$
\end{tabular}

Tabel 5 merupakan pengujian presisi menggunakan dua metode yaitu Canny edge dan Harris corner. Objek yang diukur memiliki bentuk lingkaran dengan diameter $10 \mathrm{~cm}$.

Tabel 5. Pengujian presisi objek lingkaran

\begin{tabular}{cccc}
\hline Jenis Objek & $\begin{array}{c}\text { Jarak Pengukuran } \\
(\mathrm{cm})\end{array}$ & $\begin{array}{c}\text { Diameter Objek } \\
(\mathrm{cm})\end{array}$ & $\begin{array}{c}\text { Panjang Objek } \\
\text { Terukur }(\mathrm{cm})\end{array}$ \\
\hline & & 9.76 \\
\hline Lingkaran & 100 & 10 & 9.76 \\
\hline & & 9.76 \\
\hline & & 9.76 \\
\hline & Presisi & 9.76 \\
\hline
\end{tabular}


Tabel 6 merupakan pengujian presisi yang hanya menggunakan metode Canny edge. Objek yang diukur memiliki bentuk segi empat dengan dimensi $10 \times 10 \mathrm{~cm}$.

Tabel 6. Pengujian presisi objek segi empat

\begin{tabular}{ccccc}
\hline Jenis Objek & $\begin{array}{c}\text { Jarak } \\
\text { Pengukuran } \\
(\mathrm{cm})\end{array}$ & $\begin{array}{c}\text { Dimensi } \\
\text { Objek } \\
(\mathrm{cm})\end{array}$ & $\begin{array}{c}\text { Panjang } \\
\text { Objek } \\
\text { Terukur }(\mathrm{cm})\end{array}$ & $\begin{array}{c}\text { Lebar Objek } \\
\text { Terukur }(\mathrm{cm})\end{array}$ \\
\hline Segi empat & & 9.9 & 9.7 \\
\hline & 80 & $10 \times 10 \mathrm{~cm}$ & 9.9 & 9.7 \\
\hline & & 9.9 & 9.7 \\
\hline & & & 9.9 & 9.7 \\
\hline & Presisi & & $100 \%$ & $100 \%$ \\
\hline
\end{tabular}

Dari hasil pengujian presisi yang dilakukan menggunakan berbagai macam metode didapatkan hasil pengujian sebesar $100 \%$ atau hasil maksimal. Hasil tersebut dapat maksimal dikarenakan tidak ada perubahan cahaya atau pergerakan kamera dan objek yang diukur. Sehingga hasil pengukuran tidak mengalami perubahan.

Secara keseluruhan hasil pengujian menggunakan kamera dengan jarak baseline $26 \mathrm{~cm}$, didapatkan jarak minimum pengukuran $50 \mathrm{~cm}$ untuk objek yang memiliki dimensi $10 \times 10 \mathrm{~cm}$. Jarak minimum pengukuran dipengaruhi oleh jarak baseline kamera. Semakin jauh jarak baseline kamera mengakibatkan penurunan kemampuan kamera untuk mengambil citra objek dari jarak dekat. Sehingga citra yang diambil oleh kamera menjadi overlap, yang berakibat pada kesalahan perhitungan nilai disparitas, kesalahan tersebut akan berdampak pada hasil pengukuran jarak dan dimensi objek. Gambar 9 merupakan objek yang mengalami overlap dikarenakan jarak pengukuran yang terlalu dekat.

\section{Kesimpulan dan Saran}

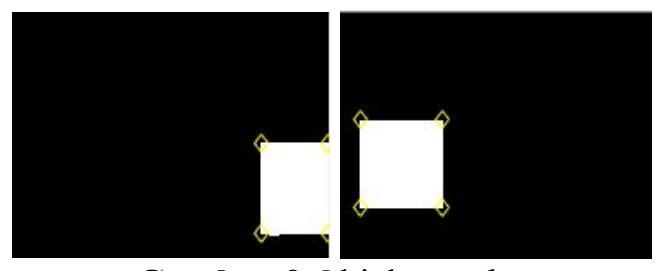

Gambar 9 Objek overlap

\subsection{Kesimpulan}

Berdasarkan dari hasil pengujian dan analisis sistem orientasi objek menggunakan metode stereo vision maka dapat diambil kesimpulkan sebagai berikut :

1. Berdasarkan pengujian yang dilakukan dalam pengukuran jarak menggunakan metode stereo vision didapatkan hasil akurasi diatas $97 \%$.

2. Metode Harris corner dapat digunakan untuk mencari nilai disparitas citra dalam melakukan pengukuran estimasi jarak dan dimensi objek.

3. Dari hasil pengujian yang dilakukan dalam pengukuran dimensi objek didapatkan tingkat presisi $100 \%$.

4. Penggunaan metode Hough line transform mengakibatkan waktu komputasi semakin besar dikarenakan metode tersebut melakukan dua kali transformasi untuk mendeteksi garis.

\subsection{Saran}

Adapun saran sebagai pengembangan berikutnya agar bisa didapatkan hasil yang lebih baik lagi adalah sebagai berikut :

1. Disarankan untuk mencari metode yang dapat digunakan untuk mengukur jarak dan dimensi objek dengan jumlah objek lebih dari satu.

2. Disarankan untuk menggunakan kamera yang stereo yang arah pandang yang benar - benar lurus kedepan atau menggunakan kamera kinect. 


\section{Daftar Pustaka}

[1] P. Tripicchio, "Autonomous navigation of mobile robots: from basic sensing to problem solving," Research on Electric and Electronic Measurement for the Economic Upturn, pp. 16, September 2014.

[2] R. Vairavan, S. Kumar Dan L. Ashiff, "Obtacle Avoidance Robotic Vehicle Using Ultrasonic Sensor, Arduino Controller," International Research Journal of Engineering and Technology, vol. II, no. 5, pp. 2140-2143, Februari 2018.

[3] R. Ismail, Z. Omar dan S.Suaibun, "Obstacle-avoiding robot with IR and PIR motion sensors," Innovation in Aerospace Engineering and technology, no. 152, pp. 1-6, 2016.

[4] C. Suharlim, E. Putra, T. Budiman dan I. H. Kartowisastro, "Estimasi Posisi Objek Berdasarkan Stereo Vision," Jurnal Teknik Komputer, vol. I, no. 21, pp. 36-47, Februari 2013.

[5] Y. D. Salman, K. R. Ku-Mahamud dan E. Kamioka, "Distance Measurement for Self-Driving Cars Using Stereo Camera," International Conference on Computing and Informatics, vol. I, no. 105, pp. 235-242, 2017.

[6] H. Tsung-Shiang dan T.-C. Wang, "An Improvement Stereo Vision Images Processing for Object Distance Measurement," International Journal of Automation and Smart Technology, vol. II, no. 5, pp. 85-90, 2015.

[7] M. Irfan, G. P. Arinata dan Z. Putra, "Segmentasi dan Estimasi Jarak Bola dengan Robot Menggunakan Stereo Vision," Symposium on Robotic Systems and Control, pp. 140-144, 2017.

[8] Y. M. Mustafah, R. Noor, H. Hasbi dan A. W. Azma, "Stereo Vision Images Processing for Real-time Object Distance and Size Measurements," International Conference on Computer and Communication Engineering, pp. 659-663, 2012.

[9] N. Rajajan, M.Ramkumar dan B.Monisha, "Disparity Estimation from Stereo Image," Science Direct, pp. 462-472, 2012.

[10] D. A. Prabowo, D. Abdullah dan A. Manik, "Deteksi dan Perhitungan Objek Berdasarkan Warna Menggunakan Color Object Tracking," Jurnal Pseudocode, vol. V, no. 2, pp. 85-91, September 2018.

[11] J. Marot dan S. Bourennane, "Raspberry Pi for Image Processing Education," European Signal Processing Conference, pp. 2428-2432, 2017.

[12] C. John, "A Computational Approach to Edge Detection," Ieee Transactions On Pattern Analysis And Machine Intelligence,, vol. 6, no. 8, pp. 679-698, 1986.

[13] H. Sa'diyah, R. Isnanto dan A. Hidayatno, “Aplikasi Transformasi Hough Untuk Deteksi Garis Lurus," Jurnal Undip, pp. 1-5, 2015.

[14] S. Javier, N. Monz' on dan A. Salgado, "An Analysis and Implementation of the Harris Corner Detector," Image Processing On Line, pp. 305-328, 2018. 